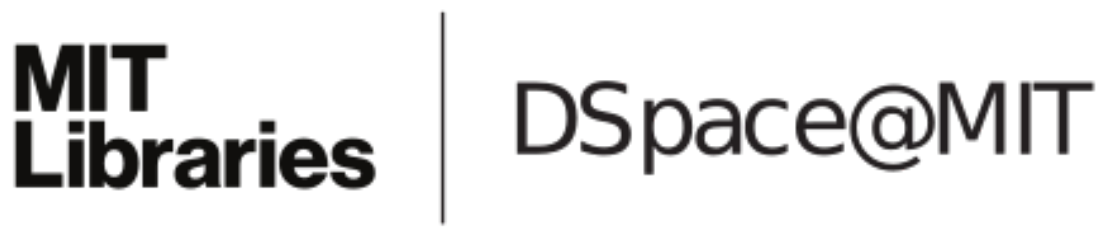

\author{
MIT Open Access Articles
}

Probing Embryonic Stem Cell Autocrine
and Paracrine Signaling Using Microfluidics

The MIT Faculty has made this article openly available. Please share how this access benefits you. Your story matters.

Citation: Przybyla, Laralynne, and Joel Voldman. “Probing Embryonic Stem Cell Autocrine and Paracrine Signaling Using Microfluidics." Annual Review of Analytical Chemistry 5, no. 1 (July 19, 2012): 293-315.

As Published: http://dx.doi.org/10.1146/annurev-anchem-062011-143122

Publisher: Annual Reviews

Persistent URL: http://hdl.handle.net/1721.1/91017

Version: Author's final manuscript: final author's manuscript post peer review, without publisher's formatting or copy editing

Terms of use: Creative Commons Attribution-Noncommercial-Share Alike 


\title{
Probing embryonic stem cell autocrine and paracrine signaling using microfluidics
}

\author{
Laralynne Przybyla ${ }^{1}$ and Joel Voldman ${ }^{2}$ \\ ${ }^{1}$ Dept. of Biology, Massachusetts Institute of Technology, 77 Massachusetts Avenue, Cambridge, \\ MA, USA, 02139 \\ ${ }^{2}$ Dept. Of Electrical Engineering and Computer Science, Massachusetts Institute of Technology, \\ 77 Massachusetts Avenue, Cambridge, MA, USA, 02139
}

\begin{abstract}
While stem cell fate is traditionally manipulated by exogenously altering the cells' extracellular signaling environment, the endogenous autocrine and paracrine signals produced by the cells also contribute to their two essential processes: self-renewal and differentiation. Autocrine and/or paracrine signals are fundamental to both embryonic stem cell self-renewal and early embryonic development, but the nature and contributions of these signals are often difficult to fully define using conventional methods. Microfluidic techniques have been used to explore the effects of cellsecreted signals by controlling cell organization or providing precise control over the spatial and temporal cellular microenvironment. Here we review how such techniques have begun to be adapted for use with embryonic stem cells, and illustrate how many remaining questions in embryonic stem cell biology could be addressed using microfluidic technologies.
\end{abstract}

\section{Keywords}

Self-renewal; Temporal cues; Development; Cell patterning; Transport analysis

\section{Introduction}

Cellular phenotype is heavily influenced by the extracellular environment. Cells constantly create and respond to external signals, including soluble secreted factors, direct cell-cell communications through gap junctions and cadherins, and extracellular matrix-based signals. These external signals in turn drive signaling cascades that lead to maintenance or alteration of cellular phenotype. Thus, technologies that aid in elucidating and controlling these external cues are critical to understanding cell biology and harnessing cells commercially or therapeutically.

Stem cells in particular are highly influenced by their extracellular environment because of their pliability. Stem cells are capable of creating new copies of themselves indefinitely-a property known as self-renewal-while maintaining the ability to differentiate into 
specialized cell types (1). External cues strongly influence whether a stem cell decides to self-renew or differentiate, and one question in stem cell biology is determining the set of signals required to dictate any given stem cell decision.

One set of external cues of particular importance to stem cell biology is the set of soluble signals that the stem cells themselves produce and respond to, known as autocrine signals, as well as signals produced by other cell types in their microenvironment, known as paracrine signals. These signals can act at short distance, down to the scale of a single cell (2), or can signal over many cell diameters (3). These autocrine and paracrine cues have been shown to affect diverse processes in stem cells, including self-renewal $(4,5)$, growth $(6,7)$, and differentiation (8), and may contribute to heterogeneity in stem cell cultures $(5,9)$. In short, they are incredibly important. However, their ubiquitous presence (i.e., they are difficult to remove) and intrinsic closed-loop nature (i.e., they may be difficult to detect externally) make them technically challenging to study in any cell system and in stem cells in particular.

Microfluidics provides opportunities to address these technical challenges. By allowing control of cells and their environment with spatial resolution down to single cells and timescales down to subseconds, microfluidic systems have an important role to play in teasing apart the complex interactions involved in stem cell autocrine and paracrine signals. In this review, we describe how microfluidics can be applied to the study of autocrine and paracrine signaling in stem cells. We employ an expansive definition of microfluidics, including methods that involve manipulation of liquids as well as those that involve micronscale control of cells (e.g., cell patterning). To keep focus, we concentrate on questions in embryonic stem cell biology, though many of the technologies can applied to related questions in other stem cell systems.

We first provide an introduction to embryonic stem cell self-renewal and early differentiation, leading to a set of open questions in the field. We then describe existing methods to study autocrine and paracrine signaling in stem cells, providing context for the subsequent description of how microfluidics can aid in studying those questions. For the microfluidic technologies presented, we provide caveats and issues to consider when designing and implementing the techniques.

\section{Autocrine and paracrine signals involved in embryonic stem cell processes}

\section{Embryonic stem cells}

Embryonic stem cells (ESCs) are pluripotent cells - they are able to differentiate into all embryonic lineages - derived from the inner cell mass (ICM) of a blastocyst $(10,11)$. In addition to being pluripotent, they are also able to self-renew by dividing while maintaining their pluripotent state, or to differentiate by dividing and exiting their pluripotent state to adopt other phenotypes. ESCs have been derived from several mammals (10-16), but mouse $(10,11)$ and human $(12)$ ESCs (mESCs and hESCs, respectively) are most commonly studied. ESCs are readily available from cell banks and can be derived de novo, are relatively straightforward to culture, and can divide indefinitely in culture without losing their pluripotency. The cells' ability to differentiate into all tissues in the adult explains their 
clinical significance, in that they have the potential to form cells or tissues for regenerative medicine, and clinical trials using hESC-derived cells are underway (17).

\section{Autocrine and paracrine signaling}

Autocrine and paracrine signaling canonically refer to soluble signals produced by cells to which they respond (autocrine) or to which neighboring cells respond (paracrine) (18). In this review we will use the term autocrine signaling to refer to signals secreted by a cell that may bind to that cell or to a neighboring cell of similar phenotype, while paracrine signaling refers to signals produced by a cell to which that cell type cannot respond, but other cell types can. Also, we will differentiate between signals added to the culture media versus soluble signals released by the cells with the terms exogenous and endogenous, respectively.

\section{Self-renewal}

Self-renewal is the most fundamental process that ESCs undergo, and is interesting both from a basic cell biological view (i.e., how do ESCs decide to stay as ESCs) and biotechnological (i.e., how do we design bioprocesses that allow expansion of ESCs to therapeutic scales while maintaining pluripotency). Thus, significant effort has been expended over the last $\sim 30$ yrs to understand ESC self-renewal, resulting in the identification of exogenous signals important for this process. hESCs and mESCs have differing self-renewal requirements, thought to arise because of their different origins and/or species-specific differences. mESC pluripotency can be retained by addition of LIF with serum, or in serum-free media with LIF and BMP4 $(19,20)$. hESCs do not self-renew in LIF media, but instead require exogenous Activin and Fgf2 $(21,22)$. Although exogenously added soluble factors are capable of inducing self-renewal, are they sufficient? One cannot answer this question without knowing the contributions of endogenous factors.

Several mESC autocrine factors have been identified that influence proliferation (Figure 1A), including Activin, Nodal and Cyclophilin A $(6,7)$. LIF has also been shown to act in an autocrine fashion (23-25), though not at levels sufficient to maintain self-renewal, while autocrine Wnt signaling has been shown to be required for $\mathrm{mESC}$ self-renewal (4). Other factors likely contribute, but their activities are obscured in standard culture settings.

The known autocrine pathways in hESCs are mostly distinct from those found in mESCs (Figure 1B). Fgf2 has been shown to be an autocrine factor $(26,27)$, a role that is reinforced in normal cultures by exogenous Fgf2 addition (28). Part of the mechanism is thought to be due to a paracrine loop that forms in hESC cultures, whereby some fraction of the population differentiates to a more fibroblast-like state that then secretes IGF-II in response to exogenous Fgf2, which in turn serves to keep the hESCs in a self-renewing state (5). TGF $\beta$ /Activin signaling has also been proposed as an autocrine loop for maintenance of hESC self-renewal (29), and Activin addition may induce autocrine Fgf2 production in hESCs (30). GDF3, also in the TGF $\beta$ superfamily, is secreted from hESCs and acts to block BMP and thus inhibit differentiation (31), while autocrine levels decrease during differentiation (32). And, as in mESCs, endogenous Wnts have been shown to help maintain hESCs in an uncommitted state, acting in hESCs by blocking neuronal differentiation (33). 
Determination of the signals that affect pluripotency in vitro is related to our understanding of early embryonic development, as the pluripotent state in vivo is transient and proper development requires an exit from this state as a result of maternal and embryonic autocrine and paracrine signaling (Figure 1C). Indeed, paracrine communication between cells that make up the inner cell mass and the trophectoderm or between extraembryonic cells and adjacent epiblast cells has been shown to be an important part of early mouse embryonic growth $(34,35)$, and blastocyst implantation requires paracrine LIF expression in the uterus (36). Thus, a number of endogenous factors have been shown that influence stem cell selfrenewal and embryonic development, and completely elucidating these signals is important for understanding ESC biology and for fully exploiting the cells therapeutically and commercially.

\section{Exit from self-renewal}

Although constant addition of factors can induce continual self-renewal of ESCs, the dynamics of factor additions play a crucial role in the exit from self-renewal and subsequent differentiation. Many differentiation protocols use timed exposure to various exogenous growth factors $(37,38)$ to drive cells to particular endpoints, often in an attempt to recapitulate timing of corresponding developmental stages. Timing of autocrine /paracrine factor presentation is also important. For example, signaling from the autocrine growth factor Fgf 4 through Erk1/2 is required for the adoption of an early neural fate in mESCs (39-41). The timing of Fgf4 presentation is important, and researchers have used pulsed addition of inhibitors to standard cultures to show that only a short period of Erk1/2 activation is required, though the exact temporal requirements have not been fully defined (39).

Fgf signaling also plays an important role in development, and again, the timing of signal presentation plays a crucial role $(42,43)$. In one example, during ICM maturation, cells from the ICM segregate and become either primitive endoderm or epiblast. The mechanism behind this segregation was unknown until recently: either the cells segregated based on position, or based on external stimuli. Recent work has identified endogenous Fgf signaling through MAP kinase as the determining characteristic and found a temporal requirement for Fgf-MAPK signaling in vivo (42) (Figure 1D). Thus, in the case of both neural precursor formation in vitro or the formation of epiblast in vivo, the timing of autocrine/paracrine signaling is important.

In another example, researchers sought to determine when specific additions were critical for specification of the mesoderm lineage, as assessed by Mixl1 expression (44). The critical timing periods for BMP4, Wnt3a, and Activin A additions were found to differ, where if timing was off, Mixl1 expression was not induced (Figure 1E). These signals were also found to induce paracrine loops to propagate mesoderm induction. However, the temporal windows described were resolved only to days or half-days, which may not correspond to the true temporal resolution. 


\section{Areas of further study}

Though significant progress has been made in understanding the involvement of cellsecreted signals in ESC processes, many questions remain, of which two broad areas are classified below.

The first involves determination of all the signaling components important in maintaining ESC self-renewal. While many components have been shown to be important or sufficient, the inability to remove the contribution of autocrine signals means that we still don't know which signaling pathways are minimally required and which are important but dispensable. Is there one overarching pathway that is required, or are several required in conjunction? Are there separate pathways that alone can provide the necessary signaling to maintain selfrenewal? In order for us to fully understand the fundamental processes required for maintenance of pluripotency, we need to know precisely which signals are necessary versus expendable, as well as understanding which signals contribute to the opposite phenomenon-exit from self-renewal.

The second question involves determining the dynamics of autocrine and paracrine signaling involved in the exit from the self-renewing state in vitro and the corresponding early embryonic state in vivo. These temporal requirements are important in terms of exogenous additions that are frequently used to mimic paracrine signals sensed in vivo, and in terms of endogenous signaling, as rapid cell-cell signaling may occur in vivo to trigger differentiation pathways. A thorough understanding of when the presence or absence of certain signals is required for a particular early cell fate decision will also aid in understanding the mechanisms behind why cells decide to self-renew versus differentiate, and will allow for improved directed differentiation.

\section{Conventional methods for investigating autocrine and paracrine signaling}

Cell-secreted factors are the "dark matter" of soluble signaling; they are there in abundance but challenging to study due to their intrinsic closed-loop nature. Below we describe the approaches that have been undertaken to address questions of autocrine and paracrine signaling. These methods have been quite successful, but their remaining limitations present opportunities for microfluidic techniques.

\section{Pathway inhibition}

When specific factors or receptors that are part of an autocrine /paracrine signaling pathway are known, the best way to investigate the contributions of the pathway is via inhibition with knockout cell lines or specific inhibitors. Many small molecule inhibitors have been identified that are specific to receptors or downstream signaling molecules, and blocking antibodies can be developed to target known proteins or receptors. Cell lines can also be derived with specific secreted proteins or receptors knocked out. With these reagents, one can perform the definitive experiments to identify and characterize an autocrine loop (Figure $2 \mathrm{~A})$. By measuring ligand in the media and characterizing phenotype with and without receptor-blocking antibody, one can determine that (1) the cells are secreting ligand, (2) the ligand binds to the receptor, and (3) ligand binding alters phenotype $(45,46)$. Importantly, all these methods are limited to studies of known factors. 
What is currently known about autocrine signaling in ESCs has primarily been determined using these methods. For example, when autocrine Wnt signals were identified to be necessary for mESC self-renewal, it was found that addition of either a Wnt antagonist or an inhibitor of Wnt signal production were able to halt self-renewal, an effect that could be reversed with exogenous Wnt addition (4).

\section{Using global and local cell density}

When the cell-secreted factors of interest have not been identified, one approach to assess the contribution of autocrine signaling is to vary global cell density and assess densitydependence of a particular phenotype, which then sets up a search for specific autocrine factors. This approach was used after observation of the density-dependent growth of mESCs (Figure 2B) to determine that this phenotype was dependent in part on the presence of the autocrine growth factor Cyclophilin A (7). However, varying density does not provide a complete picture, as autocrine signals can be sufficient at clonal density (47), and autocrine signaling and contact-mediated signaling both typically vary with cell density.

Instead, one can study autocrine signaling by quantifying phenotype based on spatial position and local cell density. Quantitative single-cell immunocytochemistry combined with computational modeling was used with mESCs to determine that, in the absence of LIF, radial organization of self-renewal markers was observed, with higher marker expression in areas of higher local cell density. This phenomenon was attributed to an unknown autocrine non-LIF gp130 ligand (24) (Figure 2C). Spatial variation was also found in hESC colonies in terms of Oct4 levels and Smad1 signaling (9), and cells at the periphery of hESC colonies have been shown to have distinct morphologies and different cell growth and death characteristics (48), all phenotypes that were attributed to the presence of autocrine and paracrine cues.

While varying global cell density or measuring local cell density in traditional cultures can be useful, it can be challenging to control for varying colony morphologies and to standardize immunofluorescent staining across experiments. A particular challenge with imaging mESCs is that the colonies grow as multi-layered clumps, so studies measuring fluorescent intensity in two dimensions require a way to functionalize the surface so that colonies spread out (24), or a way to image cells in three dimensions.

\section{Conditioned media and co-culture studies}

An alternative to varying cell density is to use conditioned media assays. Experiments in which media that has been exposed to one population of cells to 'condition' it (i.e., to load it with cell-secreted factors) and then transferred to a separate cell population have been used in studies of both autocrine and paracrine signaling. In studies of autocrine signaling, conditioned media can be used as a surrogate for cell density, as cells can be grown sparsely and then conditioned media added to simulate culture at high density; this approach has been used to find that autocrine factors are important for maintenance of a short G1 cell cycle phase in hESCs (49).

Conditioned media studies are even more powerful when studying paracrine signaling. Many in vitro protocols for differentiation of ESCs rely on conditioned media or on co- 
culture with other cell types (50-52). One common method involves use of a transwell, an insert that allows paracrine signals to pass between cells cultured in a single well but separated by a protein-permeable membrane. Conditioned media was used to determine the effect of exogenously added Fgf2 on the maintenance of hESC cultures. Exogenous Fgf2 is normally added in hESC cultures that consist of hESCs and feeder cells. However, it was found that Fgf2 is not required for maintenance of the hESCs, but is instead required for signaling to their feeder cells, which results in upregulation and secretion of other proteins that are required for hESC self-renewal (27) (Figure 2D). Though useful, conditioned media assays may suffer from inconsistency, as the complement of growth factors present may vary based on cell seeding density, growth time, and preparation and storage of conditioned media.

\section{Microfluidic approaches to study cell-secreted signaling}

While conventional approaches provide methods for uncovering the presence of autocrine and paracrine signaling pathways, revealing their importance, and identifying specific intercellular molecules that are or are not involved, there are issues that microfluidic approaches are better able to address. Specifically, microfluidic approaches can help provide a precise quantitative understanding of spatial and temporal parameters, thus allowing for more controlled studies of the cell-secreted signaling environment.

\section{Physics and scaling}

To control cell-secreted signaling, the modes by which secreted molecules are transported in liquids need to be considered. In general, ligand is produced by "source" cells at some rate (molecules/sec), can bind back to cell surface receptors (reaction sink), diffuse away, or be convected away (e.g., by fluid flow) (Figure 3A). By allowing for small-scale manipulations, microfluidics can be used to arrange cells to define regions of ligand sources and sinks, and the predictability of microscale fluid flow allows for precise control over ligand transport.

Controlling cell arrangement at the microscale allows for control of local cell density. Density, in turn, determines the endogenous ligand sources and sinks, which can be varied in autocrine systems by altering colony size or spacing between colonies, while relative densities or distributions of different cell types can alter these parameters in paracrine systems. To directly control transport of ligand in the media, nondimensional numbers can be used to compare different modes of transport, and thus determine the appropriate microfluidic operation regime. A diffusion "velocity" can be estimated by $D / L$, where $D$ is the ligand diffusivity (for a $\sim 20 \mathrm{kD}$ cytokine, $D \sim 10^{-6} \mathrm{~cm}^{2} / \mathrm{s}$ ), and $L$ is a characteristic length (e.g., the chamber height). Similarly, a reaction velocity can be defined as $k_{o n} R_{S}$, where $k_{o n}$ is the ligand binding on-rate (in $\mathrm{M}^{-1} \mathrm{~s}^{-1}$ ) and $R_{S}$ is the receptor density (in $\mathrm{mol} / \mathrm{m}^{2}$ ), and the convection velocity is simply $v$, the characteristic fluid velocity in the system. Ratios of these values lead to the Peclet number (convection/diffusion, $v L / D$ ), the Damkohler group I (reaction/convection, $k_{o n} R_{s} / v$ ) and the Damkohler group II (reaction/diffusion, $k_{\text {ons }} L / D$. By altering these transport phenomena, one can alter the balance between diffusion, convection, and reaction, and in turn modulate the activity of autocrine loops to discover their effects on phenotype. 
Microfluidics allows a decrease of $L$ and the application of $v$, and thus allows tuning of both diffusion and convection. To increase endogenous signaling, one wishes to operate in a convection-free environment $(v=0)$ with reaction occurring at a comparable rate or faster than diffusion. While $v$ is often assumed to be zero in macroscale static cultures, convection may still occur to some extent, so zero flow can be more accurately achieved by growing cells in enclosed chambers. To decrease soluble signaling, one wishes to decrease the effect of reaction, which can be accomplished by increasing convection.

\section{Organizing the cells: cell patterning}

Microtechnologies that enable cell patterning and organization have been adopted to investigate cell-cell signaling, either within colonies of cells or between colonies of the same or different cell types. Microscale ESC patterns can be created by using substrates that include chemically modified regions to which cells can attach $(53,54)$, or physically constraining cell location $(55,56)$ (Figure 3B). Regardless of method, micropatterning can be used in a number of ways to further understand how autocrine and paracrine signaling affect ESCs, for example, by uncovering endogenous signals involved in ESC processes, by determining the contributions of paracrine signals, or by recapitulating the in vivo microenvironment.

When assessing the contribution of a density-dependent signal such as an autocrine signal, the size of a colony of cells will affect ligand source and sink levels. Thus, controlling colony size can help to remove source /sink variations when quantifying the impacts of autocrine signaling. Likewise, modulating signaling by altering colony size can indicate whether cell fate is density-dependent. For example, Peerani and colleagues patterned hESCs into different-sized colonies using microcontact printing and assessed the ESCs' phenotype using quantitative immunocytochemistry, ultimately implicating endogenous BMP2 and GDF3 as modulators of self-renewal (9) (Figure 3C). Related studies with $\mathrm{mESCs}$ patterned at different colony sizes indicated the importance of endogenous Stat 3 activation on self-renewal and showed that transcription downstream of Stat 3 can be regulated by colony size (57).

To pattern cells without functionalizing the surface, stencil patterning is perhaps the simplest approach (58) (Figure 3B, Figure 3E), and multiple cell types can be organized using patterning. Tuleuova et al. used collagen /fibronectin micropatterns to pattern mESCs, and used a silanized background surface to constrain the mESC patterns (59). Because the silane was only moderately non-permissive, patterned mESCs could be back-filled with stellate cells to study paracrine interactions in hepatic differentiation (Figure 3D). Aqueous twophase patterning is another substrate-independent patterning method that has been successfully applied to ESCs $(60,61)$. This method uses a pipette to deposit one aqueous phase (containing cells) into a solution of a second immiscible aqueous phase; the cellcontaining phase maintains its as-deposited pattern, thus patterning the cells (Figure 3F). This method has been used to show that mESC neuronal differentiation increases with increasing colony size (61). One challenge with substrate-independent patterning is that, by its very nature of allowing for freedom of movement, this type of patterning makes longterm control and tracking of cells difficult, especially for motile cells such as ESCs. 
Cell patterning can also help create experimentally convenient in vitro models of vivo environments. Bio-flip chip (BFC) cell patterning creates patterns by overturning a cellloaded microwell array onto a recipient substrate, whereupon the cells fall out of the well and onto the recipient substrate while maintaining their arrangement (62). This technique has been combined with stenciling to pattern mESCs along with other cell populations found in the blastocyst to create developmental models to study early embryonic patterning events in vitro (63) (Figure 3G). Other microscale approaches to control organization include flowing droplet arrays consisting of multiple cell types, which have been used to create controlled co-cultures in small media volumes (64), and laminated microfluidic flows to modulate cell soluble signaling versus contact-mediated signaling (65), a technique that could be applied to stem cells. A more common way to control organization during ESC differentiation involves the use of three-dimensional aggregates of differentiating ESCs called embryoid bodies (EBs), whose size or shape can be controlled using microfluidics to bias differentiation, presumably by altering endogenous soluble or contact-mediated signaling $((66,67)$, Figure $3 \mathrm{H})$. By controlling EB size, it has been shown that larger EBs contribute more towards the ectoderm lineage than smaller EBs (66), and that differentiation can be tailored towards cardiac induction (67). One can also extrinsically control signaling in EBs by growing them in microfluidic traps that allow for formation of gradients (68), by providing two separate culture conditions for a single embryoid body (69), or by using microparticles to incorporate soluble factors within EBs (70). These approaches provide a platform for mimicking the microenvironment of the early embryo, in which morphogen gradients and signal polarities are important for early developmental decisions.

While controlling cell organization is useful in that it allows for assessment of cell-cell signaling in a controlled setting, these techniques are most commonly used in a static culture environment in which autocrine and paracrine signals are continually present. Another set of methods is required to alter the transport of ligand to augment or block the signaling entirely.

\section{Controlling transport: microscale culture in enclosed environments}

Methods to culture cells in enclosed microfluidic environments are fairly mature and have been applied to systems from neurobiology (71) to pulmonary biology (72). In the context of studying endogenous soluble signaling, the methods can be divided into those that try to maximize ligand concentration and those that aim to minimize it.

One can use microfluidics to confine cells in small volumes to increase the concentration of their secreted soluble signals, using small PDMS chambers or microdroplets loaded with cells $(73,74)$ (Figure 4A). These methods have been used for high-throughput antigen screening (75), or to capture and lyse single cells to check for the presence of specific signaling events (76). Using small-scale culture environments to increase endogenous signaling in ESCs is not common, however, likely because of concerns about nutrient limitations (90), and because convection is not a fundamental problem with traditional cultures (i.e., gradients in autocrine factors within colonies can be observed, which would be obscured if convection always dominated), so the added difficulty of working in an enclosed microenvironment must be balanced against the new information that could conceivably be 
obtained. Alternatively, one can use microfluidic systems to remove soluble signals from stem cell cultures. The fundamental requirement for these systems is that they have some mechanism for exchanging the medium in the culture chamber. Thus, these systems are typically comprised of PDMS microfluidic chambers with inlets and outlets, and often have valves $(77,78)$ and debubblers (79) to provide additional functionality.

Several microfluidic platforms have been described for the culture of ESCs, primarily to minimize reagent volumes for screens. For example, Kamei et al. developed a valved PDMS microfluidic platform that allowed for hESC culture in chemically defined conditions for screening and quantitative imaging (80) (Figure 4B), while another study used a simple microfluidic channel to deliver stimuli to different parts of single hESC colonies (81). Flow has also been used in microscale cultures to periodically replace the media in cell cultures to minimize nutrient depletion while allowing periodic accumulation of secreted factors, as was shown for hESCs grown on a feeder layer that required a short pulse of media every 2-4 hours (82).

While these studies provide optimized platforms for growth or screening of stem cells, determination of the cell-secreted signals that are sufficient and necessary to maintain ESC self-renewal can also be aided by the precise control afforded by microfluidics. The use of microfluidics to control soluble factor mass transport has been demonstrated for both hESCs (83) and mESCs $(84,85)$. For hESCs, a system was developed that could be tuned to operate in either a convection- or diffusion-dominated regime, resulting in different percentages of differentiated cells (83). This effect was primarily attributed to the effects of shear in the convection-dominated regime, but also to a decrease in soluble signaling due to the fact that the relative amount of differentiation was density-dependent. To control for the effects of shear and microscale culture, mESCs have been grown under microfluidic perfusion with or without added cell-secreted factors (85) (Figure 4C). In this study, mESCs were differentiated toward a neuroectodermal fate under perfusion, and cell-secreted factors were found to be required for cell viability during this process because their removal resulted in very little cell growth. In this way, the necessity of cell-secreted factors for a specific mESC differentiation process was verified, opening the possibility for testing ESC autocrine signal sufficiency and necessity in a variety of self-renewal and differentiation contexts.

\section{Temporal analysis}

In addition to spatial control, microfluidics can also provide control over the timing of signal addition or removal to address unanswered questions in ESC biology. As stem cells transition out of their self-renewing state and differentiate to particular cell types, timing of factor addition is critical, as it is in the developing embryo (Figure 1E). The timing of additions to ESCs in vitro is therefore applied to mimic endogenous autocrine or paracrine signaling processes that occur in vivo. Identifying those temporal requirements is necessary to understand and achieve certain developmental endpoints, both in vitro and in vivo, and provides an intriguing opportunity for microfluidics.

Although timing of signal presentation is clearly important throughout stem cell and developmental biology, controlling timing in vitro is more difficult than controlling exogenous factor identity and concentration. Multiwell plates and robotics make it feasible 
to screen different combinations and concentrations of factors, but are more limited in their ability to test different temporal profiles of factor addition. Because typical microfluidic chamber volumes for mammalian cell culture are $\sim 1 \mu$ or less, media can be exchanged very rapidly and in an automated fashion, allowing precise temporal requirements to be addressed.

Several microfluidic devices have been developed that allow for precise exogenous factor additions at specific times, but these have primarily focused on studying yeast signaling and gene regulation dynamics (86-88) (Figure 4D). These studies were able to reveal the presence of important signaling events, including negative feedback loops that acted at different timescales (86), but such devices have rarely been applied to study timing in stem cells. However, microfluidics' ability to exert temporal signal control could be combined with our increasing understanding of the exogenous signals involved in development to further study these processes in vitro and thus better control stem cell differentiation. One potential application of these systems is to study the temporal cues required to exit from self-renewal. It is known that the timing of Fgf4 signaling is critical to mESC specification and blastocyst development $(39,40,42)$, and microfluidics could provide further resolution as to the temporal windows required or sufficient for this addition to better understand how this autocrine/paracrine signal works in vivo.

Paracrine signals during development act both spatially and temporally, and both parameters can be controlled using microfluidics. Space can be controlled as described previously, while exogenous inputs can be switched to stimulate and/or inhibit pathways, as was shown by quantifying differentiation and motility of human primary mesenchymal stem cells after transient stimulation in a 96-chamber device (89). Another example involved testing different timescales of Steel factor stimulation in a microfluidic device to define when this protein is required to exit quiescence in adult hematopoietic stem cells in vitro (73) (Figure 4A). Paracrine interactions can also be temporally controlled using microfluidics, demonstrated with a valved two-chamber device where signals from one chamber could be directed to the other chamber, which was used to show that cancer-secreted cytokines stimulate the transformation of fibroblasts into myoblasts (90).

Using microfluidics to mimic the in vivo environment can be extended to optimize protocols for directed differentiation and to better understand the interplay between exogenous factors and endogenous loops that operate during differentiation by altering timing and concentration of factor addition. Such studies are performed at moderate scale using traditional culture conditions (91), but could potentially be performed more easily and at lower cost using microfluidics.

\section{Experimental considerations}

Microfluidics provides powerful tools with which to investigate unresolved questions in cell biology. However, with any use of microfluidic systems, it is important to ensure that the advantages outweigh the significant effort involved in developing and optimizing such systems. 


\section{Cell growth}

Whether microfluidics is used alter cell organization or ligand transport, there are growth requirements that need to be considered. First, alteration of soluble signaling via microfluidics implies an alteration of bulk media volumes. At low media volumes, lack of media nutrients and/or a buildup of waste products can become an issue. This makes it difficult to interpret experimental results; is a change in phenotype of cells cultured in a noflow environment due to soluble signaling or due to nutrient issues? As long as the media is exchanged periodically in accordance with volumes in typical bulk culture conditions ( $\sim 50-500 \mathrm{pL} / \mathrm{cell} / \mathrm{hour}$ for an ESC), cells should not experience nutrient limitation.

\section{Shear stress}

Any device that uses convection to alter soluble signaling will also introduce shear stress. Shear stress at the walls of a parallel plate flow chamber is described by the following equation:

$$
\tau=(6 \mu \mathrm{Q}) /\left(\mathrm{h}^{2} \mathrm{w}\right)
$$

where $\mu$ is the viscosity, $\mathrm{Q}$ is the volumetric flow rate, and $\mathrm{h}$ and $\mathrm{w}$ represent the height and width of the chamber. Shear stresses could alter cell physiology or even remove cells from the substrate entirely. In terms of cell removal, the detachment shear stresses for fibroblasts are $~ 30-50 \mathrm{dyn} / \mathrm{cm}^{2}$ (92), and shear stresses of $5 \mathrm{dyn} / \mathrm{cm}^{2}$ have been applied to an endothelial monolayer for a week without noticeable cell detachment (93), indicating that the shear required to detach adherent cells from substrates are typically $>>1 \mathrm{dyn} / \mathrm{cm}^{2}$. For $\mathrm{mESCs}$ in particular, removal shear stresses have been reported to be $>6.5 \mathrm{dyn} / \mathrm{cm}^{2}(94)$.

Shear stresses that have been reported to alter the signaling pathways of cells are lower than those that have been reported to remove cells from a substrate. For ESC-derived endothelial cells to begin expression of endothelial and tight junction markers, a shear of $5 \mathrm{dyn} / \mathrm{cm}^{2}$ has been used (95), and induction of endothelial cell-specific genes in mouse embryonic endothelial cells to study the activation of downstream pathways has been performed using $5-25 \mathrm{dyn} / \mathrm{cm}^{2}$ (96). The effect of shear stress is likely to be context-dependent, as it is known that mechanical stresses affect self-renewing cells to a greater extent than they affect differentiated cells (97). However, while mESCs have been shown to sense shear stress and respond to it dose-dependently at stresses from $0.016-16 \mathrm{dyn} / \mathrm{cm}^{2}$ (98), ESCs have been grown indefinitely without any effects on self-renewal properties at shears up to $6.1 \mathrm{dyn} / \mathrm{cm}^{2}$ (99). Thus, operating at shear stresses $\ll<1 \mathrm{dyn} / \mathrm{cm}^{2}$ is not likely to affect ESC phenotype.

\section{Adsorption and absorption}

Another issue in microscale devices, which are primarily molded out of PDMS, is the permeability of the chamber walls and surface adsorption. The gas-permeability of PDMS is often regarded as a feature, as it allows oxygen/carbon dioxide gas exchange to cells grown within PDMS chambers. However, PDMS also allows transport of water (100), which can lead to dehydration and thus convection and changes in media composition. Absorption can also be an issue for small molecules, especially hydrophobic ones (101), but will not be 
significant for the $>10 \mathrm{kD}$ proteins typically found as signaling molecules. However, the adsorption of molecules to PDMS surfaces is enhanced in high surface-area-to-volume microfluidic devices. This will tend to lower the fraction of secreted molecules that are active (the walls will act as a sink), which may bias results obtained with static enclosed cultures or in measurements of secreted molecules collected from perfused cultures. These issues have been addressed with a number of solutions, including growing cells in adequately humidified devices (73), pre-priming devices with equilibrated cell media before loading cells (84), and pre-coating PDMS devices with BSA to minimize the adsorption of cell-secreted proteins (102).

\section{Cell loading, recovery, and assay}

Successful loading of ESCs into microscale devices can be challenging as they tend to require long attachment periods and growth in clumps, in the case of hESCs. Typically, cells are loaded through a cell input chamber via syringe, with the benefit that only a small number of cells are needed for microscale chambers. Then, media manipulation (applying convection, adding exogenous stimuli) should not begin until an adequate amount of time has elapsed to allow cells to fully attach, which we have found to be between 12-18 hours after loading for mESCs. To remove cells, trypsin can be applied in the same input into which cells or media are added, then cells can be replated or used for downstream assays (Figure 4E).

The assays that can be performed on cells grown in microfluidic systems are often limited by the small cell numbers involved. This is a challenge for experiments involving stem cells, as they are, by definition, functionally defined. Thus, the phenotype that is assayed in a selfrenewal or differentiation experiment must always be carefully chosen. Most experiments that have been done in microsystems use cell growth or fluorescence as a readout, which do not require recovery or off-chip analysis of cells. However, these assays only provide information about a handful of parameters (80). Obtaining more complete phenotypic information is an open challenge in the field, but will be necessary for more sophisticated questions to be asked.

\section{Conclusion}

The endogenous signals sensed by ESCs significantly influence the future state of the cells. While much is known about how endogenous signaling affects ESC fate, many questions remain. These outstanding questions require techniques that provide precise control of cell organization, control of ligand transport in the media, and control of temporal cues. These in turn can be employed to better mimic the in vivo environment or to optimize differentiation and self-renewal in vitro. Whether microfluidics is used to manipulate endogenous or exogenous signals or create artificial microenvironments, its ability to operate on scales closer to the scale of the cell itself allows this technology to emulate the fundamental biological length and time scales. With the appropriate design and experimental considerations, microfluidic methods can significantly improve our understanding of ESC biology. 


\section{Acknowledgments}

We would like to thank Yi-Chin Toh for helpful comments regarding the manuscript. This work was supported in part by the National Institutes of Health (EB007278), the Singapore-MIT Alliance, and the National Science Foundation (0939511).

\section{Acronyms and definitions}

Autocrine

Paracrine

Endogenous

Epiblast

Trophoblast

ICM

Gastrulation

Extracellular

matrix

Germ layers

PDMS

Blastocyst

Primitive

Endoderm

Primitive Streak

Anteroposterior

Polarity
Diffusible signaling from one cell to itself or to another cell of the same cell type

Diffusible signaling from one cell type to a different nearby cell type

Emanating from a cell or a population of cells

A post-implantation blastocyst tissue that gives rise to all three germ layers that make up the adult organism

The outer cell layer of the blastocyst, consisting of trophoblast cells, which becomes the trophectoderm after gastrulation

Inner cell mass, the cells inside a blastocyst that give rise to all cells in the adult organism

Process by which the blastocyst folds inward to form the gastrula, resulting in the formation of the three germ layers

A meshwork of structural proteins, glycoproteins and growth factors that is secreted and maintained external to adherent cells Organization of cells in the gastrula into three layers, ectoderm, mesoderm, and endoderm, that make up all adult tissues

Polydimethylsiloxane, a biocompatible polymer used for many cell-based microdevices

An embryonic structure consisting of an inner cell mass that forms the embryo and a trophoblast that forms extraembryonic tissues

Cell lineage derived from the inner cell mass - forms alongside the epiblast lineage but gives rise to extraembryonic tissues

Ordered structure consisting of a band of cells that determines the site of gastrulation in the developing embryo

Difference in gene expression along the anteroposterior axis, from head to tail

\section{References}

1. Smith AG. Embryo-derived stem cells: of mice and men. Annu. Rev. Cell Dev. Biol. 2001; 17:435462. [PubMed: 11687496]

2. Mignatti P, Morimoto T, Rifkin DB. Basic fibroblast growth factor released by single, isolated cells stimulates their migration in an autocrine manner. Proceedings of the National Academy of Sciences. 1991; 88(24):11007-11011. 
3. Pribyl M, Muratov CB, Shvartsman SY. Long-Range Signal Transmission in Autocrine Relays. Biophysical Journal. 2003; 84(2):883-896. [PubMed: 12547771]

4. Berge, D ten; Kurek, D.; Blauwkamp, T.; Koole, W.; Maas, A.; Eroglu, E.; Siu, RK.; Nusse, R. Embryonic stem cells require Wnt proteins to prevent differentiation to epiblast stem cells. Nat Cell Biol. 2011 advance online publication.

5. Bendall SC, Stewart MH, Menendez P, George D, Vijayaragavan K, Werbowetski-Ogilvie T, Ramos-Mejia V, et al. IGF and FGF cooperatively establish the regulatory stem cell niche of pluripotent human cells in vitro. Nature. 2007; 448(7157):1015-1021. Found exogenous factor dependence of hESCs to be unexpectedly dependent on establishment of a heterogeneous population. [PubMed: 17625568]

6. Ogawa K, Saito A, Matsui H, Suzuki H, Ohtsuka S, Shimosato D, Morishita Y, Watabe T, Niwa H, Miyazono K. Activin-Nodal signaling is involved in propagation of mouse embryonic stem cells. Journal of Cell Science. 2007; 120(1):55 -65. [PubMed: 17182901]

7. Mittal N, Voldman J. Nonmitogenic survival-enhancing autocrine factors including cyclophilin A contribute to density-dependent mouse embryonic stem cell growth. Stem Cell Research. 2011; 6(2):168-176. [PubMed: 21112823]

8. Chung BG, Flanagan LA, Rhee SW, Schwartz PH, Lee AP, Monuki ES, Jeon NL. Human neural stem cell growth and differentiation in a gradient-generating microfluidic device. Lab Chip. 2005; 5(4):401. [PubMed: 15791337]

9. Peerani R, Rao BM, Bauwens C, Yin T, Wood GA, Nagy A, Kumacheva E, Zandstra PW. Nichemediated control of human embryonic stem cell self-renewal and differentiation. EMBO J. 2007; 26(22):4744-4755. Perhaps the first to pattern hESCs, this technique is elegantly used to investigate endogenous signaling in heterogeneous hESC cultures. [PubMed: 17948051]

10. Evans MJ, Kaufman MH. Establishment in culture of pluripotential cells from mouse embryos. Nature. 1981; 292(5819):154-156. [PubMed: 7242681]

11. Martin GR. Isolation of a pluripotent cell line from early mouse embryos cultured in medium conditioned by teratocarcinoma stem cells. Proc Natl Acad Sci USA. 1981; 78(12):7634-7638. [PubMed: 6950406]

12. Thomson JA, Itskovitz-Eldor J, Shapiro SS, Waknitz MA, Swiergiel JJ, Marshall VS, Jones JM. Embryonic Stem Cell Lines Derived from Human Blastocysts. Science. 1998; 282(5391):1145 1147. [PubMed: 9804556]

13. Thomson JA, Kalishman J, Golos TG, Durning M, Harris CP, Becker RA, Hearn JP. Isolation of a primate embryonic stem cell line. Proceedings of the National Academy of Sciences. 1995; 92(17):7844-7848.

14. Iannaccone PM, Taborn GU, Garton RL, Caplice MD, Brenin DR. Pluripotent Embryonic Stem Cells from the Rat Are Capable of Producing Chimeras. Developmental Biology. 1994; 163(1): 288-292. [PubMed: 8174785]

15. Hayes B, Fagerlie SR, Ramakrishnan A, Baran S, Harkey M, Graf L, Bar M, Bendoraite A, Tewari M, Torok-Storb B. Derivation, Characterization, and In Vitro Differentiation of Canine Embryonic Stem Cells. STEM CELLS. 2008; 26(2):465-473. [PubMed: 18065395]

16. Schneider MR, Adler H, Braun J, Kienzle B, Wolf E, Kolb H. Canine Embryo-Derived Stem Cells -Toward Clinically Relevant Animal Models for Evaluating Efficacy and Safety of Cell Therapies. STEM CELLS. 2007; 25(7):1850-1851. [PubMed: 17615273]

17. Strauss S. Geron trial resumes, but standards for stem cell trials remain elusive. Nat Biotech. 2010; 28(10):989-990.

18. Sporn MB, Todaro GJ. Autocrine secretion and malignant transformation of cells. N. Engl. J. Med. 1980; 303(15):878-880. [PubMed: 7412807]

19. Nichols J, Evans EP, Smith AG. Establishment of germ-line-competent embryonic stem (ES) cells using differentiation inhibiting activity. Development. 1990; 110(4):1341 -1348. [PubMed: 2129226]

20. Ying Q-L, Nichols J, Chambers I, Smith A. BMP Induction of Id Proteins Suppresses Differentiation and Sustains Embryonic Stem Cell Self-Renewal in Collaboration with STAT3. Cell. 2003; 115(3):281-292. [PubMed: 14636556] 
21. James D, Levine AJ, Besser D, Hemmati-Brivanlou A. TGF $\beta /$ activin/nodal signaling is necessary for the maintenance of pluripotency in human embryonic stem cells. Development. 2005; 132(6): 1273 -1282. [PubMed: 15703277]

22. Greber B, Wu G, Bernemann C, Joo JY, Han DW, Ko K, Tapia N, et al. Conserved and Divergent Roles of FGF Signaling in Mouse Epiblast Stem Cells and Human Embryonic Stem Cells. Cell Stem Cell. 6(3):215-226. [PubMed: 20207225]

23. Davey RE, Onishi K, Mahdavi A, Zandstra PW. LIF-mediated control of embryonic stem cell selfrenewal emerges due to an autoregulatory loop. FASEB J. 2007; 21(9):2020-2032. [PubMed: 17356004]

24. Davey RE, Zandstra PW. Spatial Organization of Embryonic Stem Cell Responsiveness to Autocrine Gp130 Ligands Reveals an Autoregulatory Stem Cell Niche. Stem Cells. 2006; 24(11): 2538-2548. [PubMed: 16825607]

25. Zandstra PW, Le HV, Daley GQ, Griffith LG, Lauffenburger DA. Leukemia inhibitory factor (LIF) concentration modulates embryonic stem cell self-renewal and differentiation independently of proliferation. Biotechnol Bioeng. 2000; 69(6):607-617. [PubMed: 10918135]

26. Dvorak P, Dvorakova D, Koskova S, Vodinska M, Najvirtova M, Krekac D, Hampl A. Expression and Potential Role of Fibroblast Growth Factor 2 and Its Receptors in Human Embryonic Stem Cells. Stem Cells. 2005; 23(8):1200-1211. [PubMed: 15955829]

27. Greber B, Lehrach H, Adjaye J. Fibroblast Growth Factor 2 Modulates Transforming Growth Factor $\beta$ Signaling in Mouse Embryonic Fibroblasts and Human ESCs (hESCs) to Support hESC Self-Renewal. Stem Cells. 2007; 25(2):455-464. [PubMed: 17038665]

28. Eiselleova L, Matulka K, Kriz V, Kunova M, Schmidtova Z, Neradil J, Tichy B, et al. A Complex Role for FGF-2 in Self-Renewal, Survival, and Adhesion of Human Embryonic Stem Cells. STEM CELLS. 2009; 27(8):1847-1857. [PubMed: 19544431]

29. Xu R-H, Sampsell-Barron TL, Gu F, Root S, Peck RM, Pan G, Yu J, et al. NANOG Is a Direct Target of TGF[beta]/Activin-Mediated SMAD Signaling in Human ESCs. Cell Stem Cell. 2008; 3(2):196-206. [PubMed: 18682241]

30. Xiao L, Yuan X, Sharkis SJ. Activin A Maintains Self-Renewal and Regulates Fibroblast Growth Factor, Wnt, and Bone Morphogenic Protein Pathways in Human Embryonic Stem Cells. STEM CELLS. 2006; 24(6):1476-1486. [PubMed: 16456129]

31. Levine AJ, Levine ZJ, Brivanlou AH. GDF3 is a BMP inhibitor that can activate Nodal signaling only at very high doses. Developmental Biology. 2009; 325(1):43-48. [PubMed: 18823971]

32. Levine AJ, Brivanlou AH. GDF3, a BMP inhibitor, regulates cell fate in stem cells and early embryos. Development. 2006; 133(2):209 -216. [PubMed: 16339188]

33. Wexler EM, Paucer A, Kornblum HI, Palmer TD, Geschwind DH. Endogenous Wnt Signaling Maintains Neural Progenitor Cell Potency. STEM CELLS. 2009; 27(5):1130-1141. [PubMed: 19418460]

34. Murohashi M, Nakamura T, Tanaka S, Ichise T, Yoshida N, Yamamoto T, Shibuya M, Schlessinger J, Gotoh N. An FGF4-FRS2a-Cdx2 Axis in Trophoblast Stem Cells Induces Bmp4 to Regulate Proper Growth of Early Mouse Embryos. STEM CELLS. 2010; 28(1):113-121. [PubMed: 19890878]

35. Mesnard D, Donnison M, Fuerer C, Pfeffer PL, Constam DB. The microenvironment patterns the pluripotent mouse epiblast through paracrine Furin and Pace4 proteolytic activities. Genes \& Development. 2011; 25(17):1871 -1880. [PubMed: 21896659]

36. Stewart CL, Kaspar P, Brunet LJ, Bhatt H, Gadi I, Kontgen F, Abbondanzo SJ. Blastocyst implantation depends on maternal expression of leukaemia inhibitory factor. Nature. 1992; 359(6390):76-79. [PubMed: 1522892]

37. Wichterle H, Lieberam I, Porter JA, Jessell TM. Directed Differentiation of Embryonic Stem Cells into Motor Neurons. Cell. 2002; 110(3):385-397. [PubMed: 12176325]

38. Kouskoff V, Lacaud G, Schwantz S, Fehling HJ, Keller G. Sequential development of hematopoietic and cardiac mesoderm during embryonic stem cell differentiation. Proceedings of the National Academy of Sciences of the United States of America. 2005; 102(37):13170 -13175. [PubMed: 16141334] 
39. Stavridis MP, Lunn JS, Collins BJ, Storey KG. A discrete period of FGF-induced Erk1/2 signalling is required for vertebrate neural specification. Development. 2007; 134(16):2889 -2894. [PubMed: 17660197]

40. Kunath T, Saba-El-Leil MK, Almousailleakh M, Wray J, Meloche S, Smith A. FGF stimulation of the Erk1/2 signalling cascade triggers transition of pluripotent embryonic stem cells from selfrenewal to lineage commitment. Development. 2007; 134(16):2895 -2902. [PubMed: 17660198]

41. Lanner F, Lee KL, Sohl M, Holmborn K, Yang H, Wilbertz J, Poellinger L, Rossant J, Farnebo F. Heparan Sulfation-Dependent Fibroblast Growth Factor Signaling Maintains Embryonic Stem Cells Primed for Differentiation in a Heterogeneous State. STEM CELLS. 2010; 28(2):191-200. [PubMed: 19937756]

42. Yamanaka Y, Lanner F, Rossant J. FGF signal-dependent segregation of primitive endoderm and epiblast in the mouse blastocyst. Development. 2010; 137(5):715 -724. Established a model describing blastocyst patterning and found it to be dependent on external signaling rather than positional cues. [PubMed: 20147376]

43. Jaeger I, Arber C, Risner-Janiczek JR, Kuechler J, Pritzsche D, Chen I-C, Naveenan T, Ungless MA, Li M. Temporally controlled modulation of FGF/ERK signaling directs midbrain dopaminergic neural progenitor fate in mouse and human pluripotent stem cells. Development (Cambridge, England). 2011

44. Jackson SA, Schiesser J, Stanley EG, Elefanty AG. Differentiating Embryonic Stem Cells Pass through "Temporal Windows" That Mark Responsiveness to Exogenous and Paracrine Mesendoderm Inducing Signals. PLoS ONE. 2010; 5(5):e10706. [PubMed: 20502661]

45. DeWitt AE, Dong JY, Wiley HS, Lauffenburger DA. Quantitative analysis of the EGF receptor autocrine system reveals cryptic regulation of cell response by ligand capture. J. Cell. Sci. 2001; 114(Pt 12):2301-2313. [PubMed: 11493669]

46. Joslin EJ, Opresko LK, Wells A, Wiley HS, Lauffenburger DA. EGF-receptor-mediated mammary epithelial cell migration is driven by sustained ERK signaling from autocrine stimulation. J. Cell. Sci. 2007; 120(Pt 20):3688-3699. [PubMed: 17895366]

47. Van Zoelen EJJ, Koornneef I, Holthuis JCMT, Oostwaard MJW, Feijen A, De Poorter TL, Mummery CL, Van Buul-Offers SC. Production of Insulin-Like Growth Factors, Platelet- Derived Growth Factor, and Transforming Growth Factors and Their Role in the Density-Dependent Growth Regulation of a Differentiated Embryonal Carcinoma Cell Line. Endocrinology. 1989; 124(4):2029-2041. [PubMed: 2538320]

48. Moogk D, Stewart M, Gamble D, Bhatia M, Jervis E. Human ESC colony formation is dependent on interplay between self-renewing hESCs and unique precursors responsible for niche generation. Cytometry Part A. 2010; 77A(4):321-327.

49. Becker KA, Stein JL, Lian JB, van Wijnen AJ, Stein GS. Human embryonic stem cells are premitotically committed to self-renewal and acquire a lengthened G1 phase upon lineage programming. J. Cell. Physiol. 2010; 222(1):103-110. [PubMed: 19774559]

50. Banerjee I, Sharma N, Yarmush M. Impact of co-culture on pancreatic differentiation of embryonic stem cells. Journal of Tissue Engineering and Regenerative Medicine. 2011; 5(4):313-323. [PubMed: 20717889]

51. Kawasaki H, Mizuseki K, Nishikawa S, Kaneko S, Kuwana Y, Nakanishi S, Nishikawa S-I, Sasai Y. Induction of Midbrain Dopaminergic Neurons from ES Cells by Stromal Cell-Derived Inducing Activity. Neuron. 2000; 28(1):31-40. [PubMed: 11086981]

52. Lam ML, Hashem SI, Claycomb WC. Embryonic stem cell-derived cardiomyocytes harbor a subpopulation of niche-forming Sca-1+ progenitor cells. Mol Cell Biochem. 2010; 349(1-2):6976. [PubMed: 21127947]

53. Chen CS, Mrksich M, Huang S, Whitesides GM, Ingber DE. Geometric control of cell life and death. Science. 1997; 276(5317):1425-1428. [PubMed: 9162012]

54. Kane RS, Takayama S, Ostuni E, Ingber DE, Whitesides GM. Patterning proteins and cells using soft lithography. Biomaterials. 1999; 20(23-24):2363-2376. [PubMed: 10614942]

55. Folch A, Jo BH, Hurtado O, Beebe DJ, Toner M. Microfabricated elastomeric stencils for micropatterning cell cultures. J. Biomed. Mater. Res. 2000; 52(2):346-353. [PubMed: 10951374] 
56. Flaim CJ, Chien S, Bhatia SN. An extracellular matrix microarray for probing cellular differentiation. Nat Meth. 2005; 2(2):119-125.

57. Peerani R, Onishi K, Mahdavi A, Kumacheva E, Zandstra PW. Manipulation of Signaling Thresholds in "Engineered Stem Cell Niches" Identifies Design Criteria for Pluripotent Stem Cell Screens. PLoS ONE. 2009; 4(7):e6438. [PubMed: 19649273]

58. Wright D, Rajalingam B, Selvarasah S, Dokmeci MR, Khademhosseini A. Generation of static and dynamic patterned co-cultures using microfabricated parylene-C stencils. Lab Chip. 2007; 7(10): 1272-1279. [PubMed: 17896010]

59. Tuleuova N, Lee JY, Lee J, Ramanculov E, Zern MA, Revzin A. Using growth factor arrays and micropatterned co-cultures to induce hepatic differentiation of embryonic stem cells. Biomaterials. 2010; 31(35):9221-9231. [PubMed: 20832855]

60. Tavana H, Jovic A, Mosadegh B, Lee QY, Liu X, Luker KE, Luker GD, Weiss SJ, Takayama S. Nanolitre liquid patterning in aqueous environments for spatially defined reagent delivery to mammalian cells. Nat Mater. 2009; 8(9):736-741. [PubMed: 19684584]

61. Tavana H, Mosadegh B, Takayama S. Polymeric Aqueous Biphasic Systems for Non-Contact Cell Printing on Cells: Engineering Heterocellular Embryonic Stem Cell Niches. Advanced Materials. 2010; 22(24):2628-2631. [PubMed: 20449846]

62. Rosenthal A, Macdonald A, Voldman J. Cell patterning chip for controlling the stem cell microenvironment. Biomaterials. 2007; 28(21):3208-3216. [PubMed: 17434582]

63. Toh Y-C, Blagovic K, Yu H, Voldman J. Spatially organized in vitro models instruct asymmetric stem cell differentiation. Integrative Biology. 2011 in press.

64. Tumarkin E, Tzadu L, Csaszar E, Seo M, Zhang H, Lee A, Peerani R, Purpura K, Zandstra PW, Kumacheva E. High-throughput combinatorial cell co-culture using microfluidics. Integr. Biol. 2011; 3(6):653.

65. Sung KE, Yang N, Pehlke C, Keely PJ, Eliceiri KW, Friedl A, Beebe DJ. Transition to invasion in breast cancer: a microfluidic in vitro model enables examination of spatial and temporal effects. Integr Biol (Camb). 2011; 3(4):439-450. [PubMed: 21135965]

66. Ungrin MD, Joshi C, Nica A, Bauwens C, Zandstra PW. Reproducible, Ultra High-Throughput Formation of Multicellular Organization from Single Cell Suspension-Derived Human Embryonic Stem Cell Aggregates. PLoS ONE. 2008; 3(2):e1565. These papers describe a simple method to control EB size and assess altered differentiation capacity. [PubMed: 18270562]

67. Bauwens CL, Peerani R, Niebruegge S, Woodhouse KA, Kumacheva E, Husain M, Zandstra PW. Control of Human Embryonic Stem Cell Colony and Aggregate Size Heterogeneity Influences Differentiation Trajectories. STEM CELLS. 2008; 26(9):2300-2310. These papers describe a simple method to control EB size and assess altered differentiation capacity. [PubMed: 18583540]

68. Khoury M, Bransky A, Korin N, Konak LC, Enikolopov G, Tzchori I, Levenberg S. A microfluidic traps system supporting prolonged culture of human embryonic stem cells aggregates. Biomed Microdevices. 2010; 12(6):1001-1008. [PubMed: 20665114]

69. Fung W-T, Beyzavi A, Abgrall P, Nguyen N-T, Li H-Y. Microfluidic platform for controlling the differentiation of embryoid bodies. Lab Chip. 2009; 9(17):2591. [PubMed: 19680583]

70. Bratt-Leal AM, Carpenedo RL, Ungrin MD, Zandstra PW, McDevitt TC. Incorporation of biomaterials in multicellular aggregates modulates pluripotent stem cell differentiation. Biomaterials. 2011; 32(1):48-56. [PubMed: 20864164]

71. Taylor AM, Blurton-Jones M, Rhee SW, Cribbs DH, Cotman CW, Jeon NL. A microfluidic culture platform for CNS axonal injury, regeneration and transport. Nat. Methods. 2005; 2(8):599-605. [PubMed: 16094385]

72. Huh D, Matthews BD, Mammoto A, Montoya-Zavala M, Hsin HY, Ingber DE. Reconstituting organ-level lung functions on a chip. Science. 2010; 328(5986):1662-1668. [PubMed: 20576885]

73. Lecault V, VanInsberghe M, Sekulovic S, Knapp DJHF, Wohrer S, Bowden W, Viel F, et al. Highthroughput analysis of single hematopoietic stem cell proliferation in microfluidic cell culture arrays. Nat Meth. 2011; 8(7):581-586.

74. Yu H, Alexander CM, Beebe DJ. Understanding microchannel culture: parameters involved in soluble factor signaling. Lab on a Chip. 2007; 7:726. [PubMed: 17538714] 
75. Love JC, Ronan JL, Grotenbreg GM, van der Veen AG, Ploegh HL. A microengraving method for rapid selection of single cells producing antigen-specific antibodies. Nat Biotech. 2006; 24(6): 703-707.

76. He M, Edgar JS, Jeffries GDM, Lorenz RM, Shelby JP, Chiu DT. Selective Encapsulation of Single Cells and Subcellular Organelles into Picoliter- and Femtoliter-Volume Droplets. Analytical Chemistry. 2005; 77(6):1539-1544. [PubMed: 15762555]

77. King KR, Wang S, Irimia D, Jayaraman A, Toner M, Yarmush ML. A high-throughput microfluidic real-time gene expression living cell array. Lab on a Chip. 2007; 7:77. [PubMed: 17180208]

78. Unger MA, Chou H-P, Thorsen T, Scherer A, Quake SR. Monolithic Microfabricated Valves and Pumps by Multilayer Soft Lithography. Science. 2000; 288(5463):113 -116. [PubMed: 10753110]

79. Kang JH, Kim YC, Park J-K. Analysis of pressure-driven air bubble elimination in a microfluidic device. Lab on a Chip. 2008; 8:176. [PubMed: 18094777]

80. Kamei, K-ichiro; Guo, S.; Yu, ZTF.; Takahashi, H.; Gschweng, E.; Suh, C.; Wang, X., et al. An integrated microfluidic culture device for quantitative analysis of human embryonic stem cells. Lab on a Chip. 2009; 9:555. [PubMed: 19190791]

81. Villa-Diaz LG, Torisawa Y-suke, Uchida T, Ding J, Nogueira-de-Souza NC, O'Shea KS, Takayama S, Smith GD. Microfluidic culture of single human embryonic stem cell colonies. Lab on a Chip. 2009; 9:1749. [PubMed: 19495459]

82. Korin N, Bransky A, Dinnar U, Levenberg S. Periodic "flow-stop" perfusion microchannel bioreactors for mammalian and human embryonic stem cell long-term culture. Biomedical Microdevices. 2008; 11:87-94. [PubMed: 18802754]

83. Cimetta E, Figallo E, Cannizzaro C, Elvassore N, Vunjak-Novakovic G. Micro-bioreactor arrays for controlling cellular environments: Design principles for human embryonic stem cell applications. Methods. 2009; 47(2):81-89. [PubMed: 18952171]

84. Kim L, Vahey MD, Lee H-Y, Voldman J. Microfluidic arrays for logarithmically perfused embryonic stem cell culture. Lab Chip. 2006; 6(3):394. [PubMed: 16511623]

85. Blagovic K, Kim LY, Voldman J. Microfluidic Perfusion for Regulating Diffusible Signaling in Stem Cells. PLoS ONE. 2011; 6(8):e22892. Used microfluidic perfusion to describe a previously unknown functionalrequirement for secreted factors in ESC neural specification. [PubMed: 21829665]

86. Mettetal JT, Muzzey D, Gómez-Uribe C, van Oudenaarden A. The Frequency Dependence of Osmo-Adaptation in Saccharomyces cerevisiae. Science. 2008; 319(5862):482 -484. [PubMed: 18218902]

87. Bennett MR, Pang WL, Ostroff NA, Baumgartner BL, Nayak S, Tsimring LS, Hasty J. Metabolic gene regulation in a dynamically changing environment. Nature. 2008; 454(7208):1119-1122. [PubMed: 18668041]

88. Charvin G, Cross FR, Siggia ED. Forced periodic expression of G1 cyclins phase-locks the budding yeast cell cycle. Proceedings of the National Academy of Sciences. 2009; 106(16):6632 6637.

89. Gómez-Sjöberg R, Leyrat AA, Pirone DM, Chen CS, Quake SR. Versatile, Fully Automated, Microfluidic Cell Culture System. Analytical Chemistry. 2007; 79(22):8557-8563. [PubMed: 17953452]

90. Hsu T-H, Xiao J-L, Tsao Y-W, Kao Y-L, Huang S-H, Liao W-Y, Lee C-H. Analysis of the paracrine loop between cancer cells and fibroblasts using a microfluidic chip. Lab Chip. 2011; 11(10):1808. [PubMed: 21491053]

91. Purpura KA, Morin J, Zandstra PW. Analysis of the temporal and concentration-dependent effects of BMP-4, VEGF, and TPO on development of embryonic stem cell-derived mesoderm and blood progenitors in a defined, serum-free media. Experimental Hematology. 2008; 36(9):1186-1198. [PubMed: 18550259]

92. Crouch CF, Fowler HW, Spier RE. The adhesion of animal cells to surfaces: The measurement of critical surface shear stress permitting attachment or causing detachment. Journal of Chemical Technology and Biotechnology. Biotechnology. 1985; 35(4):273-281. 
93. Dewey CF Jr, Bussolari SR, Gimbrone MA Jr, Davies PF. The dynamic response of vascular endothelial cells to fluid shear stress. J Biomech Eng. 1981; 103(3):177-185. [PubMed: 7278196]

94. Fok EY, Zandstra PW. Shear-Controlled Single-Step Mouse Embryonic Stem Cell Expansion and Embryoid Body-Based Differentiation. STEM CELLS. 2005; 23(9):1333-1342. [PubMed: 16081660]

95. Nikmanesh M, Shi Z, Tarbell JM. Heparan sulfate proteoglycan mediates shear stress-induced endothelial gene expression in mouse embryonic stem cell-derived endothelial cells. Biotechnology and Bioengineering.

96. Egorova AD, Van der Heiden K, Van de Pas S, Vennemann P, Poelma C, DeRuiter MC, Goumans $\mathrm{MTH}$, et al. Tgf $\beta / A l k 5$ signaling is required for shear stress induced klf2 expression in embryonic endothelial cells. Developmental Dynamics. 2011; 240(7):1670-1680. [PubMed: 21604321]

97. Chowdhury F, Na S, Li D, Poh Y-C, Tanaka TS, Wang F, Wang N. Material properties of the cell dictate stress-induced spreading and differentiation in embryonic stem cells. Nat Mater. 2010; 9(1):82-88. [PubMed: 19838182]

98. Toh Y-C, Voldman J. Fluid shear stress primes mouse embryonic stem cells for differentiation in a self-renewing environment via heparan sulfate proteoglycans transduction. The FASEB Journal. 2011; 25(4):1208 -1217.

99. Cormier JT, Nieden NIZ, Rancourt DE, Kallos MS. Expansion of Undifferentiated Murine Embryonic Stem Cells as Aggregates in Suspension Culture Bioreactors. Tissue Engineering. 2006; 12(11):3233-3245. [PubMed: 17518637]

100. Randall GC, Doyle PS. Permeation-driven flow in poly(dimethylsiloxane) microfluidic devices. Proc. Natl. Acad. Sci. U.S.A. 2005; 102(31):10813-10818. [PubMed: 16043719]

101. Regehr KJ, Domenech M, Koepsel JT, Carver KC, Ellison-Zelski SJ, Murphy WL, Schuler LA, Alarid ET, Beebe DJ. Biological implications of polydimethylsiloxane-based microfluidic cell culture. Lab Chip. 2009; 9(15):2132-2139. [PubMed: 19606288]

102. Toepke MW, Beebe DJ. PDMS absorption of small molecules and consequences in microfluidic applications. Lab on a Chip. 2006; 6:1484. [PubMed: 17203151]

103. ten Berge D, Koole W, Fuerer C, Fish M, Eroglu E, Nusse R. Wnt Signaling Mediates SelfOrganization and Axis Formation in Embryoid Bodies. Cell Stem Cell. 2008; 3(5):508-518. [PubMed: 18983966]

104. Desbaillets I, Ziegler U, Groscurth P, Gassmann M. Embryoid bodies: an in vitro model of mouse embryogenesis. Experimental Physiology. 2000; 85(6):645 -651. [PubMed: 11187960] 


\section{Summary Points}

- Cell-secreted signals are important for maintenance of ESC self-renewal, but the full repertoire of signals and their functionalities remain to be determined

- Autocrine and paracrine cell-secreted signals are critical in patterning the early embryo and their function is dependent on their proper spatiotemporal presentation

- Cell micropatterning techniques provide the ability to control cell-secreted signals by organizing the cells that produce the signals. Both autocrine and paracrine systems can be modulated.

- Using static and perfused microchambers allows control over endogenous signals that have been secreted into the media.

- By allowing control over timing of factor addition, microfluidics provides an opportunity to study the temporal requirements of endogenous and exogenous signals during differentiation.

- Applying microfluidic techniques to ESC biology requires consideration of issues including cell growth, fluid shear stress, molecular adsorption and solvent absorption, and cell handling. 


\section{Future Issues}

- Robust and accessible microfluidic systems for long-term culture and manipulation of ESCs must be developed before these systems will be widely adopted.

- Because of the small cell numbers inherent to microfluidic studies, researchers need to determine how to interface these devices with downstream assays such as RT-PCR and immunoblotting to fully exploit the power of microfluidics.

- The use of microfluidics to operate in a convection-dominated regime will allow for investigations into the cell-secreted signals required for ESC self-renewal.

- The timing and placement of signals required during differentiation can be further defined and resolved using microfluidics.

When ESCs are removed from self-renewing cues and grown in suspension, they aggregate and form three-dimensional clusters of cells known as embryoid bodies. One of the remarkable features of differentiating EBs is that they recapitulate some of the early steps of embryonic development, including formation of a primitive streak-like region, anteroposterior polarity, and the ability to differentiate into all three germ layers $(103,104)$. These features make EBs a good model system for investigating cellular processes that occur early in development, especially for humans where these processes are normally inaccessible. Developmental processes can occur to some extent in EBs that have no imposed architecture, but methods that are able to control EB organization or signaling could potentially further expand the utility of these systems. 


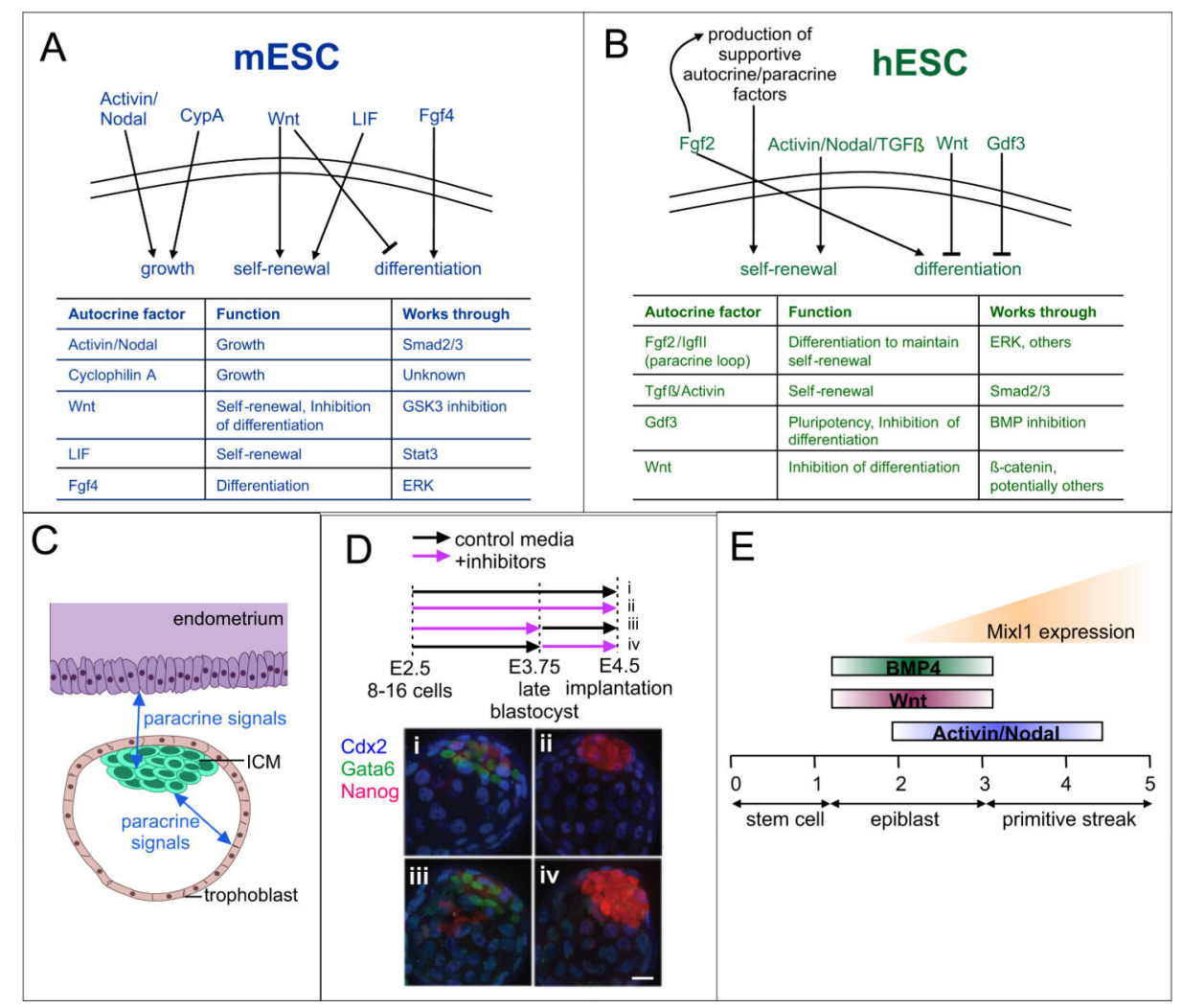

Figure 1.

ESC autocrine and paracrine signaling. (A-B) Functional autocrine-acting signals that have been identified in mESCs (A) and hESCs (B) and their roles. (C) Origin of paracrine signals involved in developmental specification in the early embryo. (D) Timing of autocrine FGF signaling affects lineage specification. Exposure of embryos to control media (i) from E2.5 to E4.5 resulted in normal development of trophectoderm ( $\mathrm{Cdx} 2$ expression), primitive endoderm (Gata6 expression), and epiblast (Nanog expression), while continuous exposure to FGF-MAPK inhibitors (ii) affected primitive endoderm development. Treatment with inhibitors at early (iii) or late (iv) timepoints shows that embryos are only sensitive to inhibition at late timepoints (iv) (42). Reproduced with permission from the Company of Biologists. (E) Depiction of time (in days) and differentiation stages during which ESCs are responsive to various stimuli (BMP4, Wnt, Activin/Nodal) for the induction of Mixl1 (adapted from (44)). 


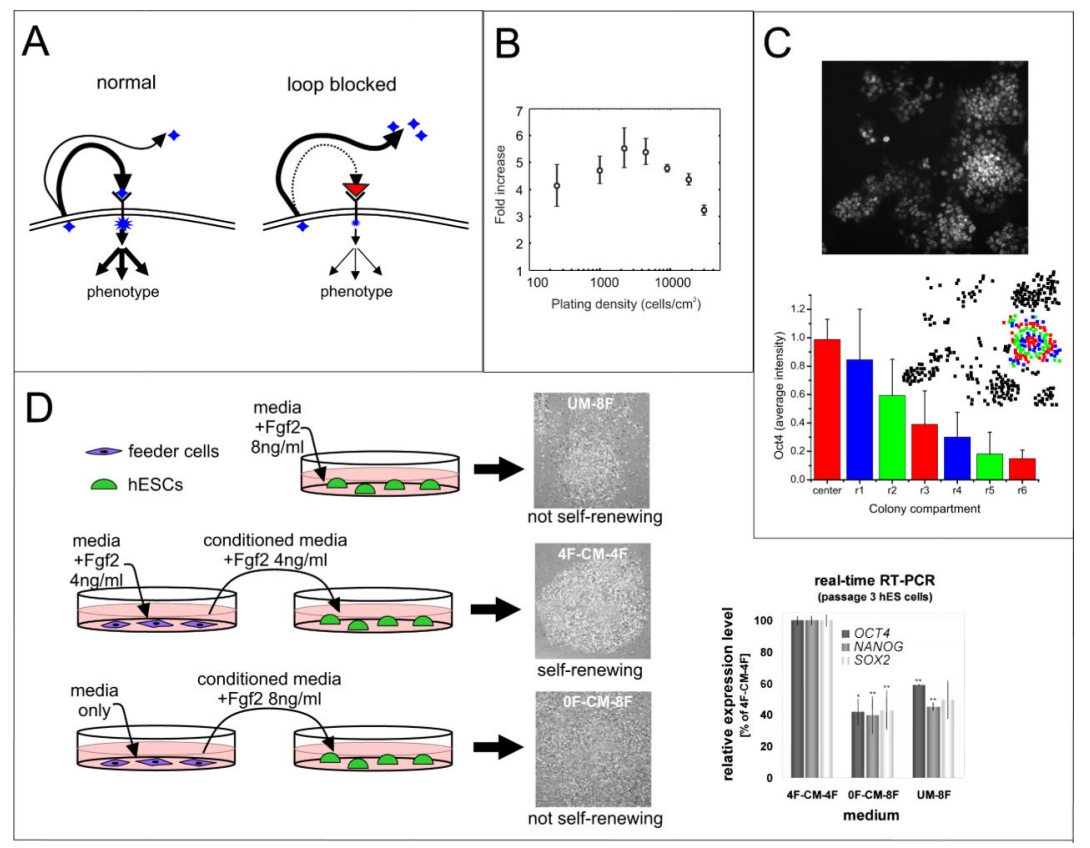

Figure 2.

Conventional methods for investigating autocrine/paracrine signaling. (A) As autocrine factors are secreted from a cell, they bind to receptors to trigger a downstream response (left), unless the receptor is blocked by a receptor-blocking antibody, in which case autocrine signals accumulate in the surrounding media (right). (B) Varying cell density to study autocrine signaling. Growth of mESCs on day 2 is found to be dependent on initial cell plating density, suggesting an autocrine loop (7). Reproduced with permission from Elsevier. (C) Using spatial information to study autocrine signaling. Image (top) of Oct4 staining in an mESC colony along with quantification (bottom) of the intensity binned into concentric rings, showing that the intensity decreases with distance from the center of the colony (24). Reproduced with permission.

Copyright 2006 John Wiley and Sons. (D) Using conditioned media to study paracrine signaling. Depiction of co-culture experiment indicating that Fgf2 produces a paracrineacting signal that is necessary for the maintenance of hESC self-renewal. Conditioned or unconditioned media with the indicated conditions was added to hESC colonies and only feeder cells that had Fgf2 added into their media were able to condition media that supported hESC self-renewal, as shown by morphology and expression of the self-renewal markers Oct4, Nanog, and Sox2 (27). Data images are reproduced with permission. Copyright 2007 John Wiley and Sons. 


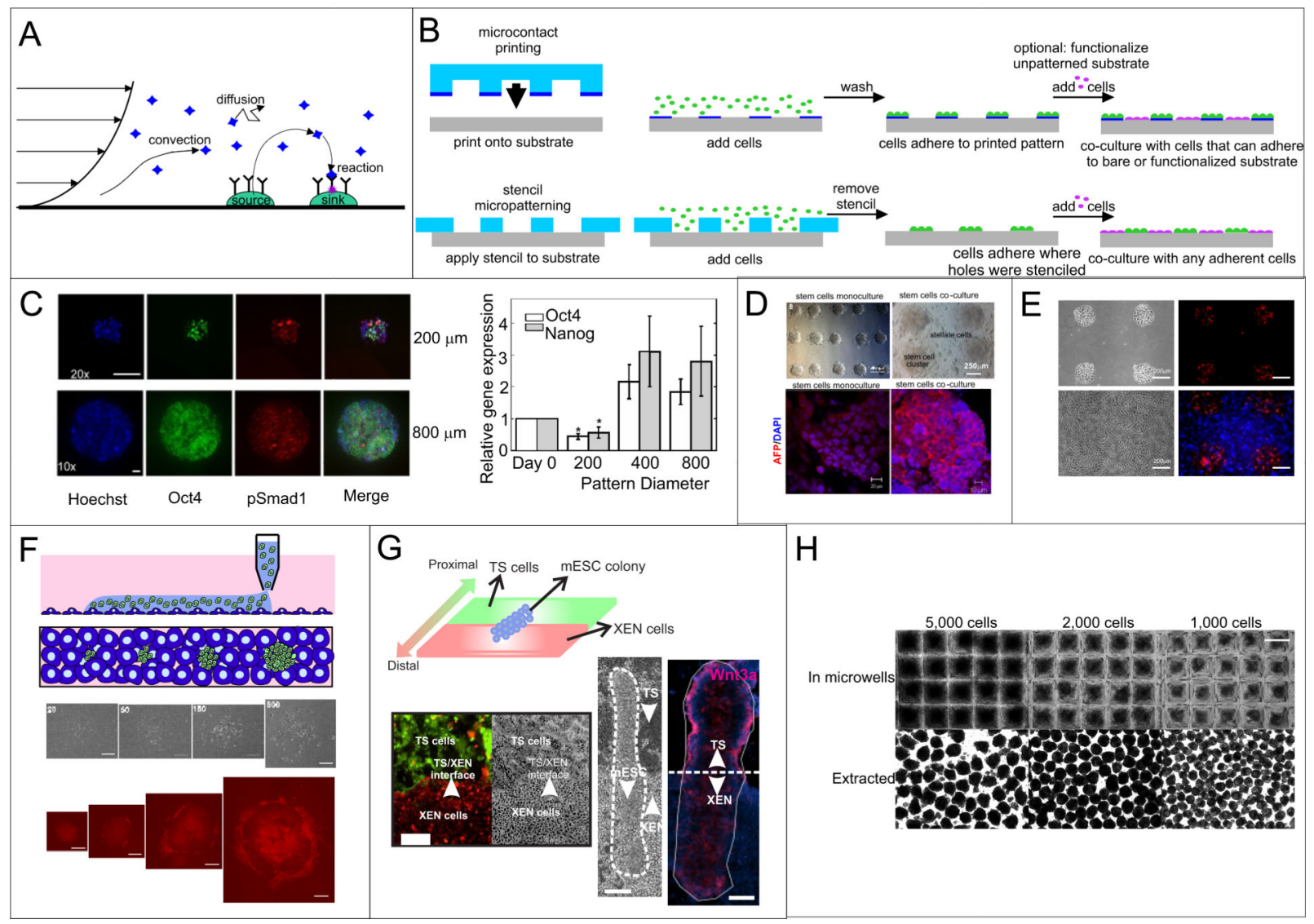

Figure 3.

Transport parameters and control over cell organization. (A) Transport modes for cellsecreted soluble signals, including diffusion, reaction, and convection of ligands from sources to sinks. (B) Depiction of cell patterning that relies on chemical modification (microcontact printing) or physical barriers (stencil patterning), including how co-culture is possible with either method. (C) Microcontact printing of hESCs onto Matrigel and immunofluorescent analysis. Images show how different markers vary from small to large colonies. Graph shows that larger colonies have higher levels of Oct4 and Nanog, likely due to increased levels of secreted factors. Reprinted by permission from Macmillian Publishers Ltd: EMBO J (9), copyright 2007. (D) Microcontact printing of mESCs without or with stellate cell co-culture (top). Analysis of AFP (hepatocyte marker) in differentiated stem cells cultured alone or with stellate cells, showing that stellate cells improve hepatic differentiation (bottom) (59). Reproduced with permission from Elsevier. (E) Stencil patterning of mESCs alone (top) or co-cultured with 3T3 cells (bottom). Cells were stained with PKH26 dye (mESCs) or CellTracker Blue (3T3s) for visualization (58). Reproduced by permission of the Royal Society of Chemistry. (F) Polymeric aqueous two-phase noncontact printing. Schematic of the approach (top). Images of cells (bottom) show that as cells are printed at increasing colony size, TuJ1 neuronal marker expression increases (61). Reproduced with permission. Copyright 2010 John Wiley and Sons. (G) Combined stencil and BFC patterning. Stencil patterning of trophoblast stem cells (TS, green) and extraembryonic endoderm cells (XEN, red) combined with BFC patterning of mESCs in a co- 
culture resembling the organization of the blastocyst induces polarized differentiation (Wnt3 staining) similar to AP polarity (63). Reproduced by permission of the Royal Society of Chemistry.(H) Use of microfabricated wells to control EB size. Images of cells in wells of three different sizes (top) and of EBs extracted from the wells (66). 


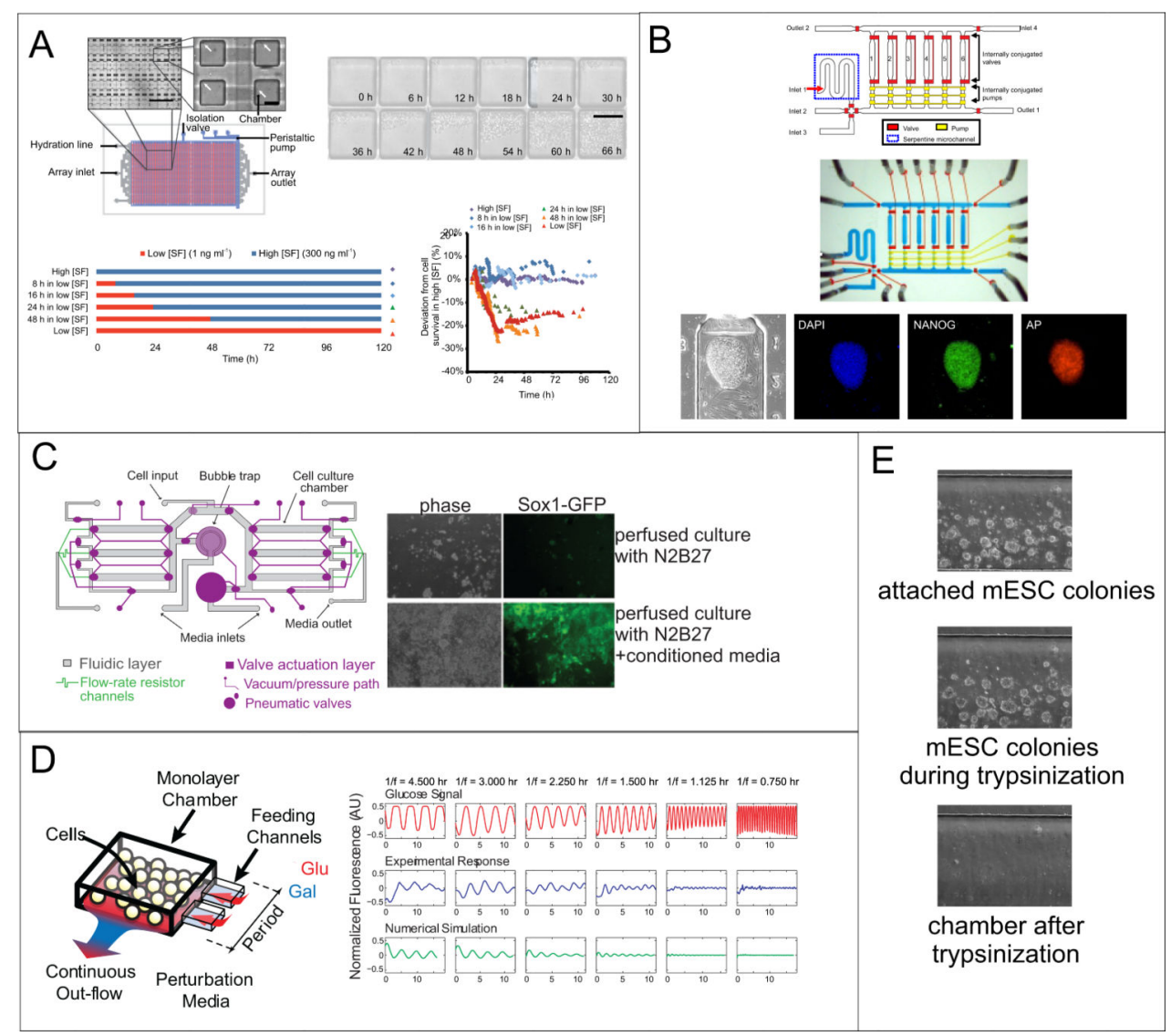

Figure 4.

Microscale stem cell culture. (A) Device for culturing cells in a system with small media volumes and minimal convection. Device layout and chambers (top left) and images of ND13 mouse preleukemic cells (top right) growing in chambers for several days. Bottom shows timecourse schematic of Steel Factor (SF) application to hematopoietic stem cells grown in chambers, and the graph shows cell survival at the indicated conditions. Cells appear to not tolerate more than 16 hours in low SF concentrations to remain viable. Reprinted by permission from Macmillian Publishers Ltd: Nature Methods (73), copyright 2011. (B) Microfluidic device for culture of hESCs. Schematic (top), optical micrograph (middle), and immunofluorescence staining of self-renewal markers (bottom) in an hESC colony grown on-chip for six days (80). Reproduced by permission of the Royal Society of Chemistry. (C) Microfluidic perfusion culture for modulating diffusible signaling. Schematic (left) of microfluidic device for multi-day culture of mESCs under continuous perfusion. Images (right) showing that only cells perfused with serum-free N2B27 media with added conditioned media (containing cell-secreted factors) were able to grow and differentiate toward neuronal precursors (Sox1-GFP expression) (85). (D) Microfluidic control of timing. Schematic (left) of a device for rapidly controlling inputs to yeast cells, showing that sinusoidal perturbations of added signals can be controlled through the feeding channels. Graphs (right) show experimental and computational results of fluorescence of a yeast fusion gene as it responds to glucose waves at varying oscillation periods. Reprinted by permission from Macmillian Publishers Ltd: Nature (87), copyright 2008. (E) ESC 
removal. mESC colonies growing in an individual culture chamber are trypsinized on-chip and collected for further analysis. 